Article

\title{
Geological Map of a Treasure Chest of Geodiversity: The Lavagnina Lakes Area (Alessandria, Italy)
}

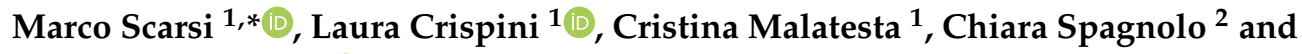 \\ Giovanni Capponi ${ }^{1}$ (D) \\ 1 Dipartimento di Scienze della Terra, dell'Ambiente e della Vita, Università degli Studi di Genova, \\ Corso Europa, 26, 16132 Genova, Italy; laura.crispini@unige.it (L.C.); cristina.malatesta@unige.it (C.M.); \\ capponi@dipteris.unige.it (G.C.) \\ 2 Independent Researcher, Chiavari, 16043 Genova, Italy; chiara.spagnolo@yahoo.it \\ * Correspondence: marco.scarsi@edu.unige.it
}

Received: 5 March 2019; Accepted: 16 April 2019; Published: 17 May 2019

\begin{abstract}
The aim of this work is to present a new georeferenced geological map of an area in the Ligurian Western Alps (Lavagnina Lakes area) that includes both a unique geodiversity and great biodiversity, a peculiar geological heritage, and cultural features. The study area is located in the northern part of the Capanne di Marcarolo Regional Natural Park, occurring in the southern Piedmont Region (Alessandria, NW Italy) and close to the suburbs of Genoa. This area has been studied by multi-disciplinary scientific researchers who, so far, have focused their attention on the occurrence of alkaline springs and investigation of different endemic floral species. Moreover, in the past, the Lavagnina Lakes area has been exploited due to the presence of gold mineralization, and several mining records are still visible. We performed detailed geological mapping at a 1:10,000 scale, and collected data that were later integrated into a digital GIS map. The database associated with the map contains information that may be interesting from different points of view: (i) scientific research; (ii) outreach and dissemination activities; and (iii) geotourism (i.e., trail networks and panoramic viewpoints). The area represents a section of the Jurassic Piedmont Ligurian oceanic lithosphere, showing several geologic processes on different scales, such as the serpentinization process and intense and widespread carbonation of ultramafic rocks; the area is, moreover, characterized by fault systems showing paleoseismic structures. Beyond scientific research activities (i.e., geology, geoarchaeology, and mining archaeology), the area can also be promoted for geotourism, outreach and dissemination activities, field trips for schools, and gold panning activities. Hence, our new digital map and our 3D model could be a useful tool to illustrate the main characteristics of the area, leading a non-expert public to explore different geological features in a relatively "small" area. In this way, our map could help to improve geotourism, be used as a tool for educational activities, and, finally, could also help the Capanne di Marcarolo Regional Natural Park to be recognized as a geopark.
\end{abstract}

Keywords: QGIS geological mapping; dissemination and outreach; natural park

\section{Introduction}

The Capanne di Marcarolo Regional Natural Park was established by the Piedmont Region (NW Italy) in 1979 as a natural protected area for its biodiversity and geodiversity (http://www. areeprotetteappenninopiemontese.it/). It originally extended over 20,000 ha but, in the past decades, it has been greatly reduced with a total areal decrease of about 12,000 ha. At present, it extends about 8200 ha (see Figure 1a) and is located among the municipalities of Casaleggio Boiro, Lerma, Mornese, Voltaggio, Tagliolo Monferrato, and Bosio (Alessandria province, Italy). The park lies between the 
Lemme, Polcevera, and Stura Valleys, spanning (in altitude) between $335 \mathrm{~m}$ (Lavagnina Lakes) and $1172 \mathrm{~m}$ (Figne Mountain) above mean sea level. Toward the south, it offers several wide panoramic views of the city of Genoa and, to the north, a wide panorama of the Western Alps. Moreover, it represents the largest green lung of the Genoa suburbs.

This region has been known since the Roman age [1] mainly for its gold mineralization; the area was, in fact, the site of mining exploitation, with the presence of a metallurgical plant devoted to the manufacturing of gold ingots, and a mining village that was inhabited from 1589 until the end of the 17th century. During the 14th century, this area was one of the possessions of the Spinola family. It was later directly annexed to the Republic of Genoa and followed the fortune of the Republic until 1859 when it was annexed to the province of Alessandria. Since the 15th century, it has been the site of trade between the Ligurians and the populations of the "Oltregiogo" [1].

After the mines were depleted in 1911, two dams were constructed, giving rise to the lakes that submerged both the metallurgical plant and the mining village.

During the Second World War, the territory was the location of fights between partisans and Nazi fascists; in 1944, more than one hundred partisans were exterminated in the former Abbey of Benedicta, where a memorial to the martyrs is presently located.

Thus, the Capanne di Marcarolo Regional Natural Park includes a peculiar geological heritage and cultural features, in addition to a unique geodiversity and great biodiversity. All the above features, associated with specific policies on land management, could attract many local and foreign visitors. The area could also aspire to be recognized as a geopark. Indeed, according to the definition by UNESCO, a geopark must include a number of geological sites of particular importance in terms of scientific quality, rarity, aesthetic relevance, or educational value.

This work focuses, in particular, on the Lavagnina Lakes district, an area where all of the peculiarities of the Capanne di Marcarolo Park are encompassed and summarized. The Lavagnina Lakes area is located in the northern part of the Capanne di Marcarolo Natural Park with an area of about $20 \mathrm{~km}^{2}$. It has been studied by several multi-disciplinary researchers with a particular focus on the occurrence of gold mineralization (exploited in the past decades), alkaline springs, and endemic floral and faunal species.

The aim of our study is to provide a new digital cartographic representation of the geology of the Lavagnina Lakes area, summarizing the main outcropping lithologies, fault systems, and representative examples of well-exposed faults, closed mine entrances, alkaline springs, trail networks, and panoramic geo-viewpoints. Therefore, we created a detailed GIS-based geological map on a 1:10,000 scale enclosing all the collected data and information into an associated database.

In view of the Capanne di Marcarolo Park possibly being recognized as a geopark, our work and our maps are useful tools to become familiar with, preserve, and enjoy the geodiversity, trails, and panoramic viewpoints of this region. 

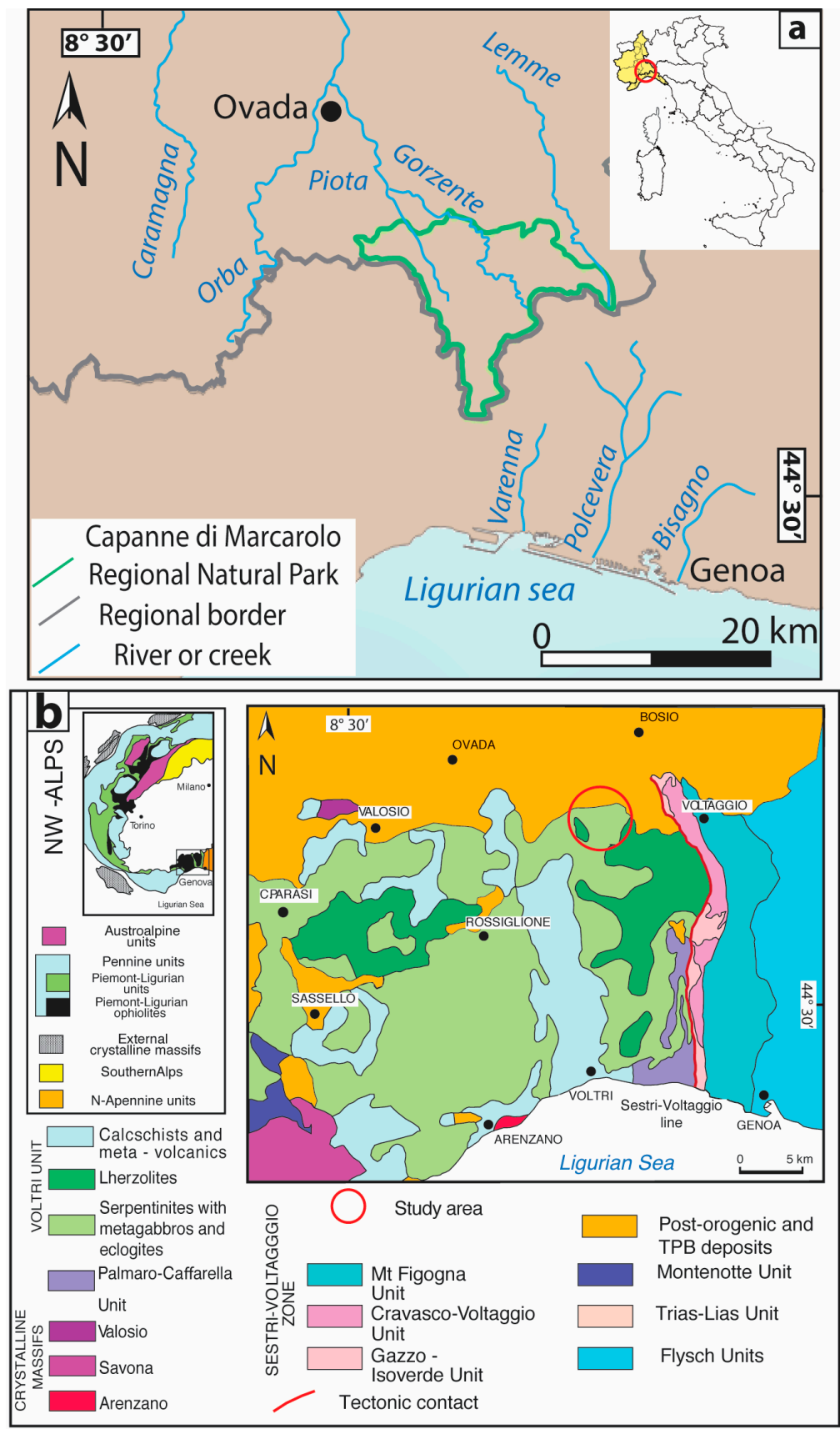

Figure 1. (Color online): (a) Geographical position of the study area; (b) Geological sketch map of the eastern Ligurian Alps and adjoining units, redrawn after Capponi and Crispini (2002); in the top left inset, a structural sketch map of the Western Alps is reported.

\section{Geological Background}

The Capanne di Marcarolo Park is located at the northeastern boundary of the Voltri Massif (Ligurian Western Alps), at the border with the Tertiary Piedmont Basin (see Figure 1b).

The Voltri Massif occurs at the southern-most termination of the Western Alps and is composed of metamorphic ophiolitic rocks with metasediments and slices of the sub-continental lithospheric mantle (see, e.g., [2]). The meta-ophiolites derive from the Jurassic Piedmont Ligurian oceanic lithosphere and consist mainly of serpentinites that include variably-sized lenses of metagabbros, metabasites, and kilometer-sized bodies of peridotites, represented by lherzolites with minor pyroxenites and dunites. 
The metasediments represent the original cover of the ophiolitic basement and encompass the whole range from quartz schists to calc-schists and mica-schists.

The Voltri Massif experienced a complex Alpine tectono-metamorphic history, recording high-pressure metamorphic peak conditions that are partially over-printed by retrogressive metamorphic assemblages [3-9]. From a structural point of view, syn-metamorphic ductile deformations are overprinted by brittle-ductile to brittle non-metamorphic structures $[5,10]$. The superposition of the ductile deformations produces a composite metamorphic foliation, which is the most evident surface in the field and controls the contacts between lithotypes.

The traces of Upper Eocene-Lower Miocene sedimentary deposits of the Tertiary Piedmont Basin (TPB) unconformably overlie the Voltri Massif rocks.

Further details on the geological framework of the area can be found in the literature $[1,5,10-12]$.

\section{Methods}

This work has been subdivided into several steps that included the following:

- a preliminary bibliographical and cartographical research and analysis that provided a useful historical and geological background, and lithological and structural features were obtained from geological surveys [11,13-16];

- the georeferencing of existing geological data about the analyzed area, using the Map Publisher software (WGS84 coordinate system);

- a detailed geological and structural survey on a 1:5000 scale during which the MotionX-GPS IOS app was used to obtain the spatial coordinates of each relevant point, and the base maps used were the Regional Technical Maps (CTRs) of the Regione Piemonte at a 1:10,000 scale. During the fieldwork stage, the CTR of the Regione Piemonte were scaled to obtain a proper working map;

- subsequent integration of all the data acquired during the fieldwork through the Quantum GIS software (WGS84 coordinate system), since GIS permits data elaboration, linking small descriptions of geological heritage, geodiversity, and single geosites to coordinates;

- the production of sketch maps (i.e., a 3D geological model of the Lavagnina Lakes area, see the Geological Map supplementary material) that were obtained from a shaded relief map, based on a digital elevation model (DEM) with $5 \mathrm{~m}$-resolution—the Qgis2threejs plugin was used for DEM and 3D model management.

The new geological map was designed on a 1:10,000 scale cartographic base in the WGS84 coordinate reference system in order to both fulfill the requested ISO standard (e.g., A0 paper size $-841 \mathrm{~mm} \times 1189 \mathrm{~mm}$, Geological Map supplementary material) and, at the same time, provide a map with good detail. Adobe Illustrator and Photoshop software were employed to draw and assemble the final map.

\section{Results}

Our new geological map covers the whole extent of the Lavagnina Lakes area (around $20 \mathrm{~km}^{2}$ ) and the associated database contains information that is interesting from different points of views:

(i) Scientific research: The database, including the position of geological structures and their elevation, paleoseismic structure positions, occurrence of carbonated fault zones and alkaline springs, geomorphological features, and gold mining-related structures could be easily modified and updated according to different kinds of studies.

(ii) Outreach and dissemination activities: With the photos of lithotypes, carbonated fault zones, alkaline springs, and gold mining-related structures that are associated with the GPS points and a brief caption, the database could be used as a starting point for these activities.

(iii) Geotourism: Trail networks and panoramic geo-viewpoints. 
Moreover, the geological map and the related database are easily queriable and, hence, in collaboration with the park authority, the map could be uploaded to the website of the park.

Among the locations of geological heritage occurring in the area, geosites, geoarcheological sites, and panoramic geo-viewpoints are mapped (see the main geological map and the 3D geological model). The map depicts the geodiversity of the area well. In particular, structural geological elements, such as fault zones, their damage zones, and peculiar fault rocks, are pointed out. Panoramic geo-viewpoints include special sites where the tectonic elements that influenced the landscape changes can be observed.

In the following, we will detail the main elements present in the map (i.e., geodiversity, gold mining activities, and geotourism-related features), giving some hints on the biodiversity of the study area.

\subsection{Geodiversity}

The geodiversity of the study area (see Figure 2 and the geological map in the supplementary materials) concerns mainly the coexistence of Jurassic Piedmont Ligurian oceanic lithostratigraphic succession; exhumed fault systems, along which an intense and widespread process of carbonation took place; and alkaline springs.

\subsubsection{Lithostratigraphic Succession}

From a geological point of view, the investigated area (see Figure 2 and geological map in the supplementary materials) is characterized mainly by outcrops of peridotites, serpentinites, metabasites, metagabbros, metasediments, and listvenites (in decreasing order of areal extension).

The peridotites are made up of partly-serpentinized lherzolites, dunites, and pyroxenites, in decreasing order of areal extension. The lherzolites (see Figure 3a) are mainly massive with a centimeter-size granular texture; mantle minerals (i.e., ortho- and clinopyroxenes, spinels, plagioclase, and locally olivine) and textures are preserved; locally, lherzolitic tectonites occur. Dunites and pyroxenites are both present as lenses or as centimeter- to decimeter-thick bands within the lherzolites. The lherzolites of the study area also show a variable degree of serpentinization until their complete transformation into serpentinites.

The serpentinites (see Figure $3 b$ ) are both massive and foliated. Massive serpentinites show pseudomorphic and non-pseudomorphic textures made by prevailing antigorite and sub-ordered magnetite. Foliated serpentinites are affected by a pervasive schistosity, defined by syn-kinematic antigorite, magnetite, and chlorite. This schistosity is parallel to the contact with other lithologies.

The metabasites are lenticular bodies inside serpentinites, and are mainly derived from basalts.

The metagabbros are lens-shaped bodies, wrapped mainly by serpentinite, and are characterized by diffusively-preserved magmatic textures. Foliated metagabbros occur at the margins of the bodies. The magmatic and oceanic low pressure-high temperature assemblages are completely replaced by the eclogitic metamorphic peak assemblage; the retrogressive overprint caused the development of the blueschist facies and of the greenschist facies assemblages.

The metasediments are mainly calc-schists and mica-schists with quartz-carbonate interlayers, characterized by a pervasive schistosity. Along the schistosity, the High Pressure-Low Temperature (HP-LT) assemblage is overprinted by greenschist paragenesis. The metasediments are frequently intensively weathered, which makes them weakly-coherent rocks.

The listvenites (see Figure 3b) consist of metasomatized mafic to ultramafic rocks (in particular, lherzolites and serpentinites), characterized by partial to total carbonation and silicification of the host rock. These rocks crop out, mainly within or near faults and shear zones, and, for this reason, in the map they are called "carbonated fault zones" (CFZ). In the study area, they consist of strongly-carbonated serpentinite with serpentinite clasts surrounded by a hydrothermal carbonated matrix of $\mathrm{Mg}-\mathrm{Fe}-\mathrm{Ca}$ carbonates and quartz, with accessory serpentine, talc, Mg-chlorite, $\mathrm{Cr}$-rich phengite (fuchsite), and ore-minerals (e.g., hematite, magnetite, $\mathrm{Fe}-\mathrm{Ni}$, or $\mathrm{Fe}-\mathrm{Cu}$ sulfides and relict chrome-spinel; see [17]). Such rocks show high textural variability that is linked to the metasomatic processes that affected them. 
At the northern border of the area, deposits of the Tertiary Piedmont Basin (TPB) also occur. The TPB is a late- to post-orogenic basin. Its deposits are mainly marine sediments (upper Eocene-upper Miocene), which unconformably overlie the Ligurian Alpine units [18]. The early stage of sedimentation of the TPB records a transgressive phase, characterized by the deposition of siliciclastic conglomerates and sandstones, marine shallow-water coarse- to fine-grained siliciclastic sediments, and reef limestones [18]. In particular, continental breccias and conglomerates mainly crop out in the area.

The continental breccias cropping out in this area are related to the "Brecce della Crosazza" [19] and are made up of limestone and dolomitic limestone clasts with rare serpentinite pebbles and cobbles. The conglomerates (see Figure 3c) are related to the "Conglomerati di Molare" and are made up of pebbles, cobbles, and boulders of serpentinites, metabasites, and local metasediments and limestone. In the area, the TPB outcrops are limited by vertical faults [10].

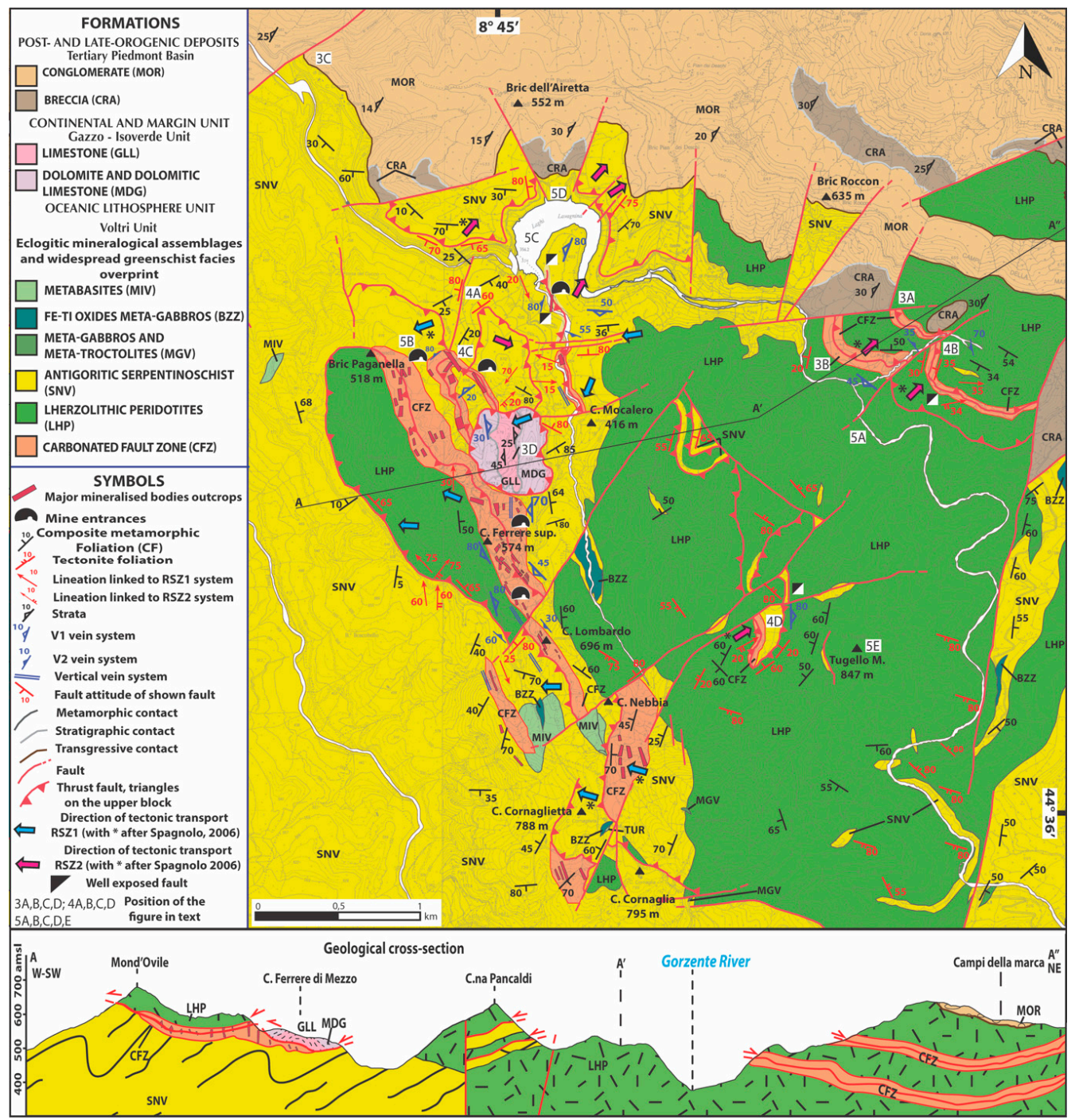

Figure 2. (Color online): Geological map of the Lavagnina Lakes area and relative geological cross-section.

The area also comprises at the Case Ferrere locality (see the geological map in the supplementary material and Figure 2) a carbonatic klippe bordered by thrust faults with a W-SW sense of shear [13]. The carbonatic klippe is made up of dolomite, dolomitic limestone, and gray crystalline selciferous limestone, related to the "Dolomie del monte Gazzo" and "Calcari di Gallaneto" (see Figure 3d) of the Gazzo-Isoverde Unit [13]. The stratigraphic succession of the carbonatic klippe is first deformed and 
overturned by isoclinal folds and then deformed by open parallel folds with upright axial planes and SE-plunging axes [13].

Hence, based on the data above, the geodiversity of the area is represented by the coexistence (in a relatively "small" area) of rocks that testify different geodynamic and tectonic settings (see the geological cross-section in Figure 2); the Lavagnina Lakes area is, in fact, characterized in more detail by:

(1) the coexistence of the Jurassic Piedmont Ligurian oceanic lithosphere with the original cover of the ophiolitic basement and continental and margin unit;

(2) the complex tectono-metamorphic evolution that affected the lithotypes, with high-pressure metamorphism and variable retrogressive overprints (e.g., blueschist facies conditions for the carbonatic klippe);

(3) the presence of upper Eocene-lower Miocene sedimentary deposits in the Tertiary Piedmont Basin; and

(4) the presence of carbonated ultramafic rocks-an exclusive feature of this area if compared with the whole Voltri Massif.
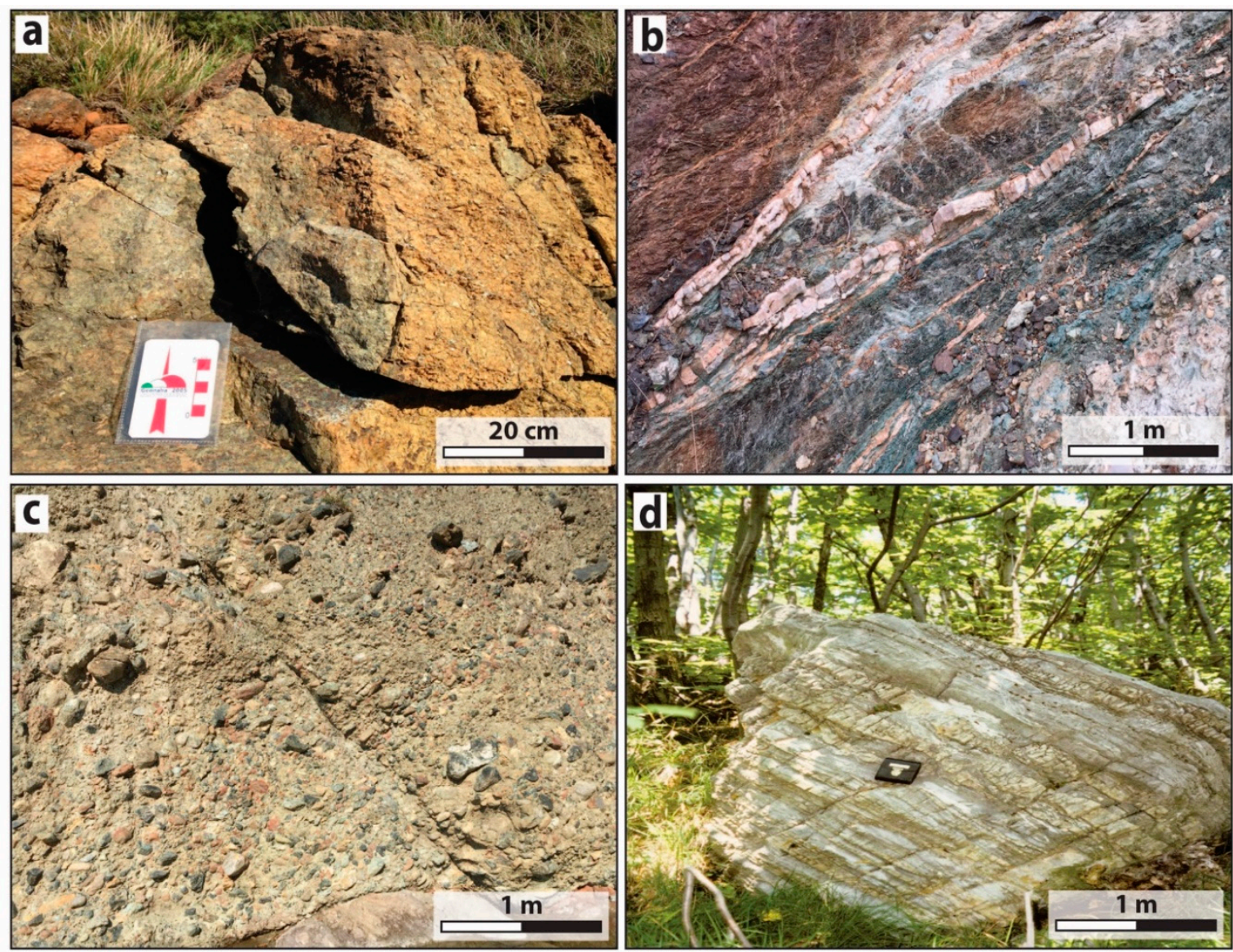

Figure 3. (Color online): Geodiversity of the area: (a) lherzolites; (b) listvenites; (c) conglomerate belonging to the "Conglomerati di Molare" (Tertiary Piedmont Basin); and (d) carbonates related to the "Calcari di Gallaneto".

\subsubsection{Exhumed Fault Systems}

From a geostructural point of view, the Lavagnina Lakes area shows the superposition of several deformations, which were developed under structural conditions evolving from brittle-ductile to brittle regimes, mainly related to alpine subduction and collisional events $[10,15,20]$.

In the area, several examples of well-exposed exhumed faults occur; all exhumed faults observed in the field are represented in Figure 2 and the geological map (supplementary materials Figure S1). 
They developed in the upper structural levels $\left(250-300{ }^{\circ} \mathrm{C}\right.$ and $\left.3-11 \mathrm{~km}\right)$ and were later exhumed; they can be referred to as "upper crustal deformations" (see Figure 2). Some of these exhumed faults, due to their structural characteristics and kinematics, can be grouped into two systems of reverse shear zones (RSZs; for more details, please refer to the literature $[11,15,16])$. Thanks to their peculiar features, these structures could be the object of scientific research and teaching activities. These structures (see Figure 4) show the following features:

(i) They are exposed, from 20 to more than $100 \mathrm{~m}$.

(ii) They have developed within lherzolites or serpentinites, or along the lithological contact between serpentinized lherzolites and serpentinites.

(iii) They show complex architectures with plurimeter-thick and asymmetric damage zones, with the development of different fault rocks, and decimeter- to meter-thick fault cores. In particular, the faults shown in Figure 4 are characterized both by structures that, in the literature, are related to paleoseismic events and intense carbonation. These faults show asymmetric damage zones [21-23], mirror-like surfaces [24,25], and occurrences of chalcedony with textures related to silica gel deposition [26,27].
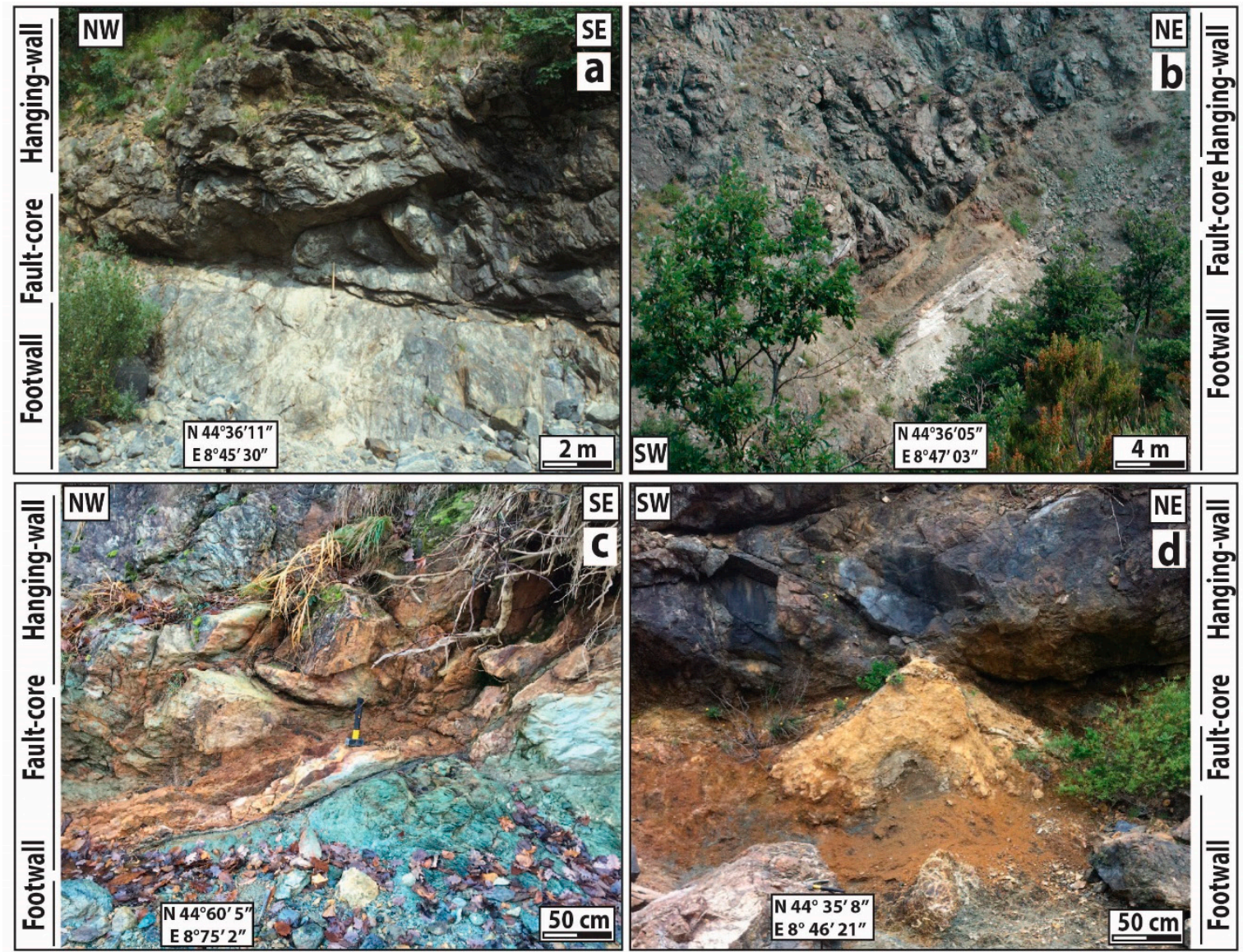

Figure 4. (Color online): Representative examples of well-exposed fault zones in the area: (a) fault developed within serpentinites; (b) fault developed at the lithological transition between lherzolites and serpentinites, characterized by intense carbonation along the fault core; and (c,d) fault developed within lherzolites, characterized by intense carbonation along the fault core.

As highlighted above, in the study area, the carbonation process that developed along the presently exposed faults affected ultramafic rocks (lherzolites with a variable degree of serpentinization and serpentinites). This process incorporated carbon dioxide into stable mineral carbonate phases, safely trapping $\mathrm{CO}_{2}$ over geological periods [28-31], and representing a natural analog of in situ artificial 
$\mathrm{CO}_{2}$ mineral sequestration. In situ $\mathrm{CO}_{2}$ mineral sequestration was proposed to reduce anthropogenic carbon dioxide pollution [32]; it is basically an induced industrial exothermic alteration of metal-rich non-carbonate minerals (e.g., $\mathrm{Mg}_{2} \mathrm{SiO}_{4}$ olivine, $\mathrm{Mg}_{3} \mathrm{Si}_{2} \mathrm{O}_{5}(\mathrm{OH})_{4}$ serpentine, $\mathrm{Mg}_{2} \mathrm{Si}_{2} \mathrm{O}_{6}$ enstatite, and $\mathrm{CaMgSi}_{2} \mathrm{O}_{6}$ diopside) to geologically and thermodynamically stable mineral carbonates (e.g., $\mathrm{MgCO}_{3}$ magnesite, $(\mathrm{Ca}, \mathrm{Mg})\left(\mathrm{CO}_{3}\right)_{2}$ dolomite, $\mathrm{CaCO}_{3}$ calcite, and $\mathrm{FeCO}_{3}$ siderite [28]).

\subsubsection{Alkaline Springs}

All the alkaline and Ca-rich springs observed in the field are located on our map (see Figure 2, Figure 5a and Figure S1). The alkaline waters flow slowly through several small pools before reaching the Gorzente River, developing, on the surrounding rocks, carbonate crusts with different thicknesses and a honeycomb structure; in particular, some of the springs develop carbonate to travertine deposits along the pools.

Most of the springs are located in variably serpentinized lherzolites; these springs were particularly studied for the water-rock interaction processes after which $\mathrm{CO}_{2}$ is sequestered, forming reduced chemical species that remain in solution until their interaction with rocks (e.g., $\mathrm{CH}_{4}$ and $\mathrm{H}_{2}$; see [33]): this represents the present-day process of carbonation described in the previous subsection.

\subsection{Gold Mining}

Gold deposits are described in many geological units of central-eastern Liguria (e.g., in the Sestri-Voltaggio Zone and in the ophiolitic rocks belonging to the Internal Ligurian Units, in northern Apennine), but in the Voltri Massif, and especially in the Gorzente Valley, there are the widest occurrences $[1,17,34-39]$.

Exploitation of the gold deposits of the analyzed area dates back to the Roman age and to the mythological city called "Rondinaria" [17]. The Roman activity is testified to by stacks of pebbles and cobbles along the Gorzente banks, similar to the stacks described along the Dora and Elvo Rivers near Ivrea; such stacks are linked to the sorting of fluvial deposits to find nuggets by Celtic populations and, later, by the Romans during the second and first centuries B.C. [17]. Along the Gorzente banks, these stacks cover a surface of some square kilometers.

The gold mineralizations from which the gold nuggets derived were also probably known in the area, but the first evidence of mining activity dates back to 1589 [17]. The mining activity continued until the early 1900s, and all the mine entrances and galleries present in the area date back to those years (see Figures 2 and $5 b$ ).

In 1911, after depletion of the mines, the construction of two dams gave rise to artificial lakes that submerged the metallurgical plant (Figure $5 \mathrm{c}$ ) and the mining village.

The gold is unevenly distributed in the peridotites and serpentinites, with an average content from $0.1-2.0 \mathrm{~g} / \mathrm{t}$ [39]. The most interesting gold mineralizations in the Lavagnina Lakes area can be divided into two types: (i) quartz-vein systems and (ii) lode mineralizations; both types of mineralization are related to fault-linked listvenites.

The mineralization correlated with the quartz-vein systems mainly cuts peridotite mantle layering and the serpentinite schistosity; here, gold is present in plagues (millimeters in size) as native dendritic gold (up to $1 \mathrm{~cm}$ in size) or associated with sulfur [39].

The lode mineralization is related to the carbonation and silicification processes of peridotites and serpentinites along the fault systems, which took place along the fault until the complete transformation of the host-rock into listvenites. The mineralized bodies show limited extension, are from a dozen to a hundred meters long, and are decimeters to meters thick; here, gold is present as plagues (millimeters in size) or associated with sulfur [39].

The gold of both mineralizations is an alloy of gold (80-85\%), silver (10-15\%), and copper $(2-3 \%)$ [39].

At present, in the surrounding areas of the Lavagnina Lakes, competitions for gold prospectors and gold panning activities for schools are organized. 

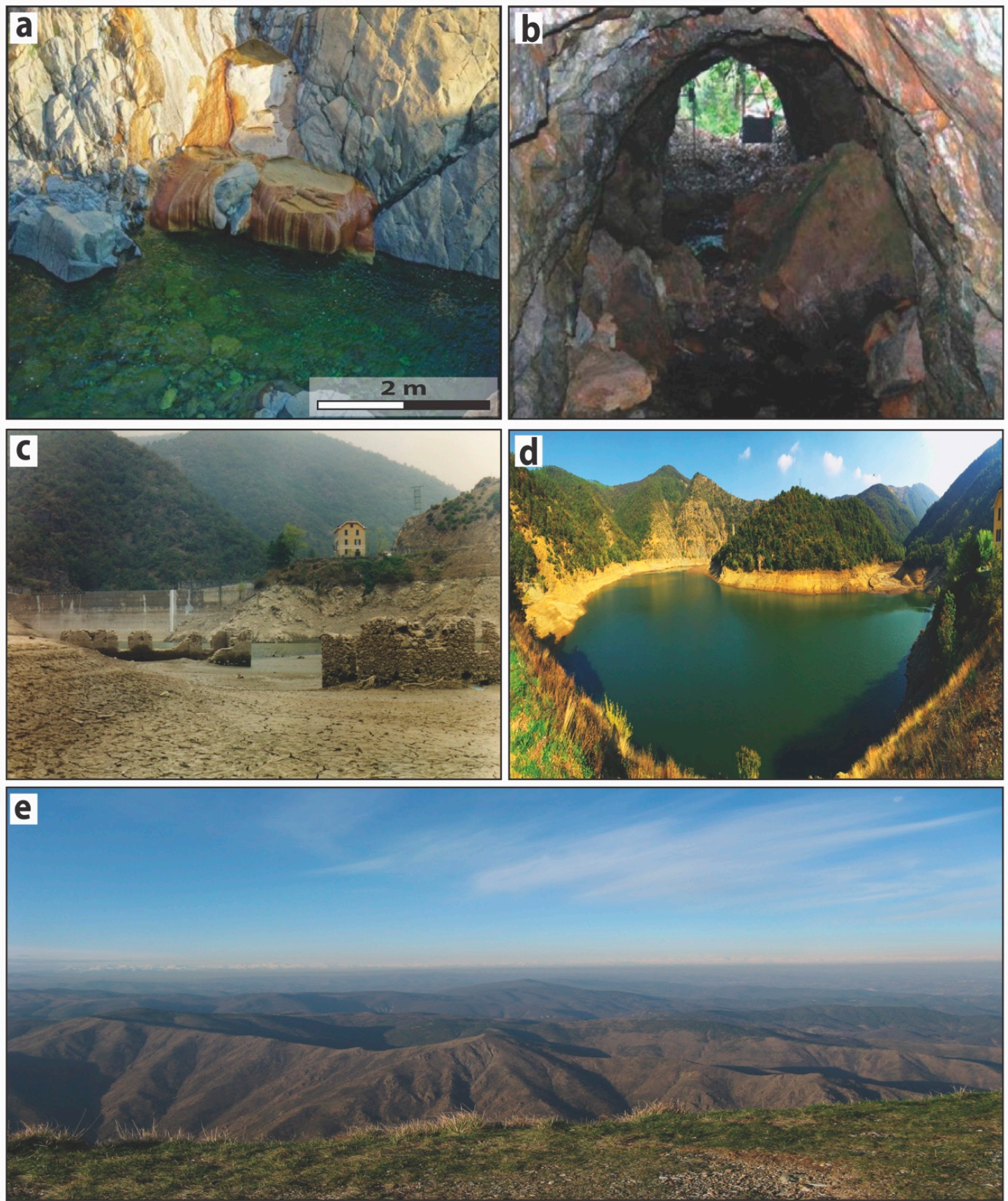

Figure 5. (Color online): (a) Alkaline spring; (b) One of the gold mine entrances to the galleries occurring in the area; (c) the ruins of the metallurgical plant is still visible at the bottom of the lake during periods of drought; (d) panoramic viewpoint of the lake from the trail that runs along it; (e) breathtaking panoramic view from the Tugello Mountain.

\subsection{Trail Network and Tourism Features}

The Lavagnina Lakes area offers many possibilities for geotourism thanks to its peculiar geodiversity, biodiversity, and geoarcheological amenities. Trail networks occurring in this area allow a deep appreciation of all the above richness in a full immersion of nature.

These trails (see the geological map in the supplementary materials) provide breathtaking panoramic viewpoints (see Figure $5 \mathrm{~d}, \mathrm{e}$ ), which can be easily reached by hiking or jogging, horse riding, or mountain biking. 
Many guided excursions and educational itineraries along the trail network, which are organized by the park authority, are functional to learning about the environmental and the cultural aspects of the territory. Hence, our geological map (see the Supplementary materials) could provide a useful guide to the users of the protected area of the park.

This area is also a privileged point for knowledge of the gold mining processes: the Natural Park, in fact, organizes guided educational tours of the abandoned gold mines and of the "Gold Museum" (Lerma Village).

This area also encloses several signifiers of important historical events, including the memorial of Benedicta in memory of the partisans exterminated by the Nazi fascist troops during the Second World War.

The Capanne di Marcarolo Park provides tourists with several facilities (e.g., car parks and picnic areas) and other attractions, such as an astronomical observatory located at Lerma Village, about $7 \mathrm{~km}$ from the closest highway.

\subsection{Biodiversity versus Geodiversity}

In addition to the geodiversity described above, the Lavagnina Lakes area also shows peculiar biodiversity. This region represents a nesting site for different species and an important locality along migratory routes (for more details, please refer to the literature $[40,41]$ ). Furthermore, the area shows biological evidence of more than 300 floral species, among which several are endemic species [42].

The studied area shows a peculiar connection between biodiversity and geodiversity. In this area, the abandonment of mines and their galleries has allowed them to be transformed into habitats with the same characteristics as natural caves; particularly, in these galleries, the presence of Speleomantes strinatii [43], a peculiar species of salamander also known as "geotritone", was reported.

\section{Final Remarks}

The new geological map that we provide is a substantial update to the previous geological maps of the Lavagnina Lakes area and of the Capanne di Marcarolo Natural Park. Our map highlights elements of the geological, geomorphological, and cultural landscapes of this region (e.g., gold exploitation-related structures), offering a means to read and interpret a complex and rapidly-changing environment. Among the occurring geological elements, we indicated, in particular, the presence of various types of fault rocks, some of them characterized by pervasive carbonation. For both the presence of carbonated fault rocks and peculiar carbonate crusts strictly related to alkaline springs, the Lavagnina Lakes area can be considered as a key area to investigate and illustrate the past and present water-rock interaction processes that cause $\mathrm{CO}_{2}$ sequestration.

The park authority was instituted to promote the fruition and protection of this environment. Currently, these purposes are only partly achieved and the consequences of the abandonment of the area are well-visible on the territory.

Therefore, this map offers new insights into the ways in which the park authority can promote sustainable fruition of this highly-valuable area, which could aspire to become a recognized geopark. Our geological map is a useful tool for the management and enhancement of what can constitute a strategic area for the development of green tourism in the Genoa area, offering useful information for geotourism (e.g., trail networks, panoramic viewpoints, and gold panning activities).

The Lavagnina Lakes area (as well as the entire Capanne di Marcarolo Natural Park) represents an excellent natural environment for its geodiversity, biodiversity, and presence of geoarcheological sites; its value can be enhanced and it can be made more exploitable by school field trips, geotourism, and by the scientific community. 
Supplementary Materials: The following are available online at http://www.mdpi.com/2076-3263/9/5/229/s1, Figure S1: Geological map of a treasure chest of geodiversity: the Lavagnina Lakes area (Alessandria, Italy).

Author Contributions: All authors contributed extensively to the work presented here. M.S. performed the conceptualization, data curation, investigation, and the writing of the original draft; L.C. took charge of the project administration and supervision; C.M. handled the supervision, the writing, and the review \& editing of the manuscript; G.C. was in charge of the supervision and funding acquisition.

Funding: This research received no external funding.

Acknowledgments: We greatly appreciate the critical review of the manuscript by Silvia Fornasaro. We acknowledge Giuseppe Pipino for field assistance. We also thank the three unnamed reviewers for their detailed and constructive comments which improved this manuscript.

Conflicts of Interest: The authors declare no conflict of interest.

\section{References}

1. Pipino, G. Oro, Miniere, Storia: Miscellanea di Giacimentologia e Storia Mineraria Italiana; Museo Storico Oro Italiano: Predosa, Italy, 2003.

2. Piccardo, G.B.; Rampone, E.; Vannucci, R. Upper mantle evolution during continental rifting and ocean formation: Evidences from peridotite bodies of the western Alpine-northern Apennine system. Mémoires Soc. Géol. Fr. 1990, 156, 323-333.

3. Cimmino, F.; Messiga, B. I calcescisti del Gruppo di Voltri (Liguria Occidentale): Le variazioni composizionali delle miche bianche in rapporto alla evoluzione tettonico-metamorfica alpina. Ofioliti 1979, 4, 269-294.

4. Scambelluri, M.; Strating, E.H.; Piccardo, G.B.; Vissers, R.L.M.; Rampone, E. Alpine olivine-and titanian clinohumite-bearing assemblages in the Erro-Tobbio peridotite (Voltri Massif, NW Italy). J. Metamorph. Geol. 1991, 9, 79-91. [CrossRef]

5. Capponi, G.; Crispini, L. Progressive shear deformation in the metasediments of the Voltri Group (Ligurian Alps, Italy); occurrence of structures recording extension parallel to the regional foliation. Boll. Soc. Geol. Ital. 1997, 116, 267-277.

6. Desmons, J.; Compagnoni, R.; Cortesogno, L.; Frey, M.; Gaggero, L.; Dallagiovanna, G.; Seno, S.; Radelli, L. Alpine metamorphism of the Western Alps: II. High-P/T and related pre-greenschist metamorphism. Schweizer. Mineral. Petrograph. Mitteil. 1999, 79, 111-134.

7. Federico, L.; Capponi, G.; Crispini, L.; Scambelluri, M. Exhumation of alpine high-pressure rocks: Insights from petrology of eclogite clasts in the Tertiary Piedmontese basin (Ligurian Alps, Italy). Lithos 2004, 74, 21-40. [CrossRef]

8. Malatesta, C.; Crispini, L.; Federico, L.; Capponi, G.; Scambelluri, M. The exhumation of high pressure ophiolites (Voltri Massif, Western Alps): Insights from structural and petrologic data on metagabbro bodies. Tectonophysics 2012, 568, 102-123. [CrossRef]

9. Scarsi, M.; Malatesta, C.; Fornasaro, S. Lawsonite-bearing eclogite from a tectonic mélange in the Ligurian Alps: New constraints for the subduction plate-interface evolution. Geol. Mag. 2017, 155, 280-297. [CrossRef]

10. Capponi, G.; Crispini, L. Structural and metamorphic signature of alpine tectonics in the Voltri Massif (Ligurian Alps, North-Western Italy). Eclogae Geol. Helvetiae 2002, 95, 31-42.

11. Spagnolo, C.; Crispini, L.; Capponi, G. Late structural evolution in an accretionary wedge: Insights from the Voltri Massif (Ligurian Alps, Italy). Geodinamica Acta 2007, 20, 21-35. [CrossRef]

12. Capponi, G.; Crispini, L.; Federico, L.; Malatesta, C. Geology of the Eastern Ligurian Alps: A review of the tectonic units. Ital. J. Geosci. 2016, 135, 157-169. [CrossRef]

13. Capponi, G.; Crispini, L.; Ferrarazzo, I. New field data on the Case Ferrere area (Voltri Massif, Ligurian Alps). Boll. Soc. Geol. Ital. 1998, 117, 87-92.

14. Spagnolo, C. Late-Orogenic Tectonics in the Eastern Sector of the Ligurian Alps. Ph.D. Thesis, Università degli Studi di Genova, Genova, Italy, 2006.

15. Federico, L.; Spagnolo, C.; Crispini, L.; Capponi, G. Fault-slip analysis in the metaophiolites of the Voltri Massif: Constraints for the tectonic evolution at the Alps/Apennine boundary. Geol. J. 2009, 44, 225-240. [CrossRef] 
16. Scarsi, M. Faulting, Fluid-Rock Interaction and Hydrothermal Mineralisation in Ultramafic Rocks (Voltri Massif, Ligurian Alps). Ph.D. Thesis, Dipartimento di Scienze della Terra dell'Ambiente e della Vita, University of Genoa, Genova, Italy, 2018.

17. Pipino, G. Le Valli dell'Oro-Miscellanea di Geologia, Archeologia e Storia dell'Ovadese e della Bassa Val d'Orba. Museo Storico dell'Oro Italiano; Tipografia Pesce: Ovada, Italy, 2001.

18. Quaranta, F.; Piazza, M.; Vannucci, G. Climatic and tectonic control on the distribution of the Oligocene reefs of the Tertiary Piedmont Basin (NW Italy). J. Geosci. 2009, 128, 587-591. [CrossRef]

19. Crispini, L.; Federico, L.; Capponi, G.; Spagnolo, C. Late orogenic transpressional tectonics in the "Ligurian Knot". Boll. Soc. Geol. Ital. 2009, 128, 433-441. [CrossRef]

20. Capponi, G.; Crispini, L. Note Illustrative della Carta Geologica d'Italia alla scala 1:50.000 Foglio 213 Genova; SELCA: Firenze, Italy, 2008.

21. Ben-Zion, Y. Dynamic ruptures in recent models of earthquake faults. J. Mech. Phys. Solids 2001, 49, $2209-2244$. [CrossRef]

22. Ben-Zion, Y.; Shi, Z.Q. Dynamic rupture on a material interface with spontaneous generation of plastic strain in the bulk. Earth Planet. Sci. Lett. 2005, 236, 486-496. [CrossRef]

23. Mitchell, T.M.; Ben-Zion, Y.; Shimamoto, T. Pulverized fault rocks and damage asymmetry along the Arima-Takatsuki Tectonic Line, Japan. Earth Planet. Sci. Lett. 2011, 308, 284-297. [CrossRef]

24. Evans, J.P.; Prante, M.R.; Janecke, S.U.; Ault, A.K.; Newell, D.L. Hot faults: Iridescent slip surfaces with metallic luster document high-temperature ancient seismicity in the Wasatch fault zone, Utah, USA. Geology 2014, 42, 623-626. [CrossRef]

25. Rowe, C.D.; Griffith, W.A. Do faults preserve a record of seismic slip: A second opinion. J. Struct. Geol. 2015, 78, 1-26. [CrossRef]

26. Faber, C.; Rowe, C.D.; Miller, J.A.; Fagereng, Å.; Neethling, J.H. Silica gel in a fault slip surface: Field evidence for palaeo-earthquakes? J. Struct. Geol. 2014, 69, 108-121. [CrossRef]

27. Prokofiev, V.Y.; Kamenetsky, V.S.; Selektor, S.L.; Rodemann, T.; Kovalenker, V.A.; Vatsadze, S.Z. First direct evidence for natural occurrence of colloidal silica in chalcedony-hosted vacuoles and implications for ore-forming processes. Geology 2017, 45, 71-74. [CrossRef]

28. Boschi, C.; Dini, A.; Dallai, L.; Ruggieri, G.; Gianelli, G. Enhanced $\mathrm{CO}_{2}$-mineral sequestration by cyclic hydraulic fracturing and Si-rich fluid infiltration into serpentinites at Malentrata (Tuscany, Italy). Chem. Geol. 2009, 265, 209-226. [CrossRef]

29. Matter, J.M.; Kelemen, P.B. Permanent storage of carbon dioxide in geological reservoirs by mineral carbonation. Nat. Geosci. 2009, 2, 837-841. [CrossRef]

30. Dockrill, B.; Shipton, Z.K. Structural controls on leakage from a natural $\mathrm{CO}_{2}$ geologic storage site: Central Utah, U.S.A. J. Struct. Geol. 2010, 32, 1768-1782. [CrossRef]

31. Kelemen, P.B.; Matter, J.; Streit, E.E.; Rudge, J.F.; Curry, W.B.; Blusztajn, J. Rates and Mechanisms of Mineral Carbonation in Peridotite: Natural Processes and Recipes for Enhanced, in situ $\mathrm{CO}_{2}$ Capture and Storage. Ann. Rev. Earth Planet. Sci. 2011, 39, 545-576. [CrossRef]

32. Seifritz, W. $\mathrm{CO}_{2}$ disposal by means of silicates. Nature 1990, 35, 486. [CrossRef]

33. Schwarzenbach, E.M.; Lang, S.Q.; Frah-Green, G.L.; Lilley, M.D.; Bemasconi, S.M.; Mehay, S. Sources and cycling of carbon in continental, serpentinite-hosted alkaline springs in the Voltri Massif, Italy. Lithos 2013, 177, 226-244. [CrossRef]

34. Pipino, G. Le manifestazioni aurifere del gruppo di Voltri con particolare riguardo ai giacimenti della Val Gorzente. Ind. Miner. 1976, 27, 452-468.

35. Pipino, G. Alcune Considerazioni sui Giacimenti delle Ofioliti Liguri; Liguria Mineraria, Museo Storico Oro Italiano: Predosa, Italy, 1978; pp. 97-107.

36. Pipino, G. Gold in Ligurian Ophiolites (Italy). In Proceedings of the International Ophiolite Symposium, Republic of Cyprus, Ministry of Agriculture and Natural Resources, Geological Survey Department, Lefkosia, Cyprus, 1-8 April 1980; pp. 756-773.

37. Buisson, G.; Leblanc, M. Gold-bearing listwaenites (carbonatized ultramafic rocks) from ophiolite complexes. In Metallogeny of Basic and Ultrabasic Rocks; Gallagher, J.M., Ixer, R.A., Neary, C.R., Eds.; The Institution of Mining and Metallurgy: London, UK, 1985; pp. 121-131.

38. Buisson, G.; Leblanc, M. Gold in carbonatized ultramafic rocks from ophiolite complexes. Econ. Geol. 1985, 80, 2028-2029. [CrossRef] 
39. Pipino, G. Liguria Mineraria. Miscellanea di Giacimentologia e Storia Estrattiva; Tipografia Pesce: Ovada, Italy, 2005.

40. Badini, M.; Fasano, S.G. Resoconto dell'attività di inanellamento degli uccelli a scopo scientifico in Piemonte e Valle d'Aosta. Riv. Piemontese Storia Nat. 2006, 27, 393-427.

41. Toffoli, R. Le Autostrade del Cielo: Rotte di Migrazione dell'Avifauna Attraverso le Alpi, Le Autostrade del Cielo"-Regione Piemonte-Osservatorio Faunistico; Regione Piemonte: Torino, Italy, 2007.

42. Marsili, S.; Barberis, G. Note floristiche piemontesi dal Parco di Capanne di Marcarolo (Alessandria). Inform. Bot. Ital. 2012, 1, 121-124.

43. Carnevale, P.; Fasano, S.G.; Oneto, F.; Puppo, M.; Raineri, V. Biodiversità e pianificazione ambientale nelle aree protette: Elaborazione della Carta della qualità naturalistica. Biol. Ambient. 2016, 30, 3-11.

(C) 2019 by the authors. Licensee MDPI, Basel, Switzerland. This article is an open access article distributed under the terms and conditions of the Creative Commons Attribution (CC BY) license (http://creativecommons.org/licenses/by/4.0/). 